Ђакон Лазар Ђачић

Црква Вазнесења Господњег, Суботица exapostilar@gmail.com

https://doi.org/10.18485/rit.2021.19.35.8
УДК: $27-558.3$ “00/03“"

$27-1$ “00/03“"

Оригинални научни рад

Датум пријема: 7.1.2021.

\title{
ПОРИЈЕКЛО И РАЗВОЈ КАТИХУМЕНАТА У ДРЕВНОЈ ЦРКВИ
}

\begin{abstract}
Резиме

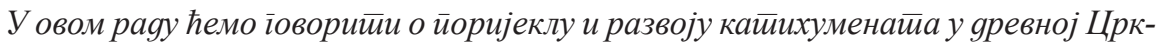

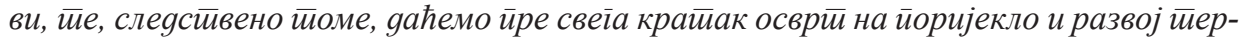

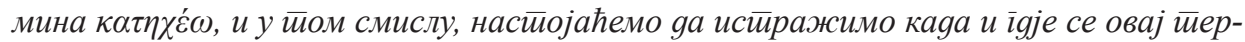
мин йрви йуй јавља, са којим значењем и како се йо юеіово значење развијало и формирало gо юеі̄ове уйойребе у хришћанској лииерайури. Наяаље ћемо іоворийи

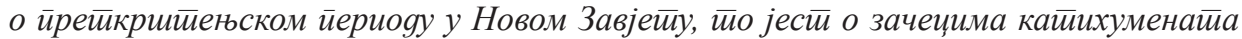

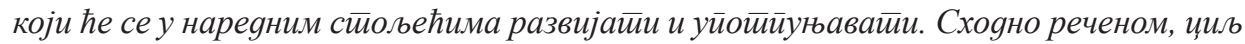
нам је gа иррвенсиивено на иримјеру јеgноі оg новозавјейних сиичса, конкрейно Дјела айосйолских, уочимо све оне иретикрийењске елемениее, који ће у каснијим вијековима йослужитии као основа за усйостиављање кайихуменайа. Тиме, у ирвом йлану,

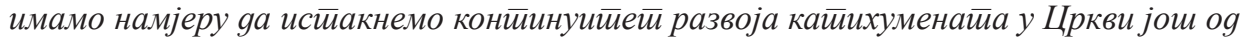
ирвих дана юеноі живойа.
\end{abstract}

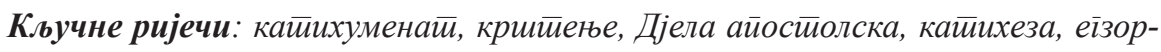
цизам, исйовијеgане вјере

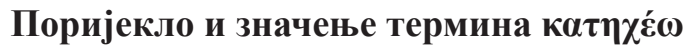

Термини као што су катихеза, катихизација, катихуменат, и слично, во-

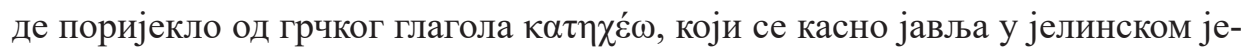
зику и, сем тога, ријетко се и употребљава. Стога, није чудно што Седамдесеторица преводилаца уопште не знају за овај термин. Чак га не срећемо ни у јеврејској вјерској литератури. Филон Александријски и Јосиф Флавије,

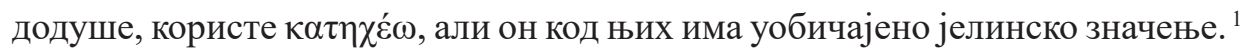

Као што видимо, овај глагол се састоји од като́ што значи оgозі̄o, и

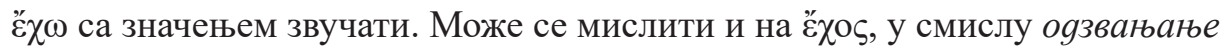

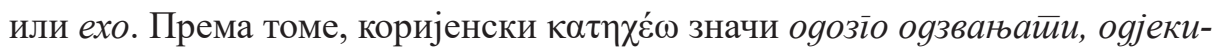

1 в. Marijan Mandac, y: Sveti Avgustin, Poučavanje neupućenih, Makarska 1988, 14. 


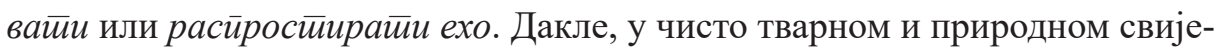

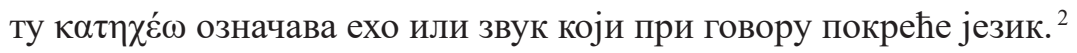

Тако, било је сасвим природно да је ова ријеч имала своју широку употребу у позоришту, јер су се у древно вријеме глумци и пјесници публици обраћали са узвишеног мјеста, па је до слушалаца ријеч долазила као ехо. Али катๆ $\chi \dot{\varepsilon} \omega$ ускоро добија изведена значења. Првенствено добија зна-

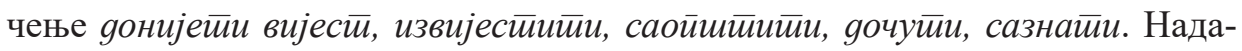

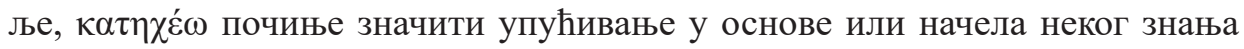

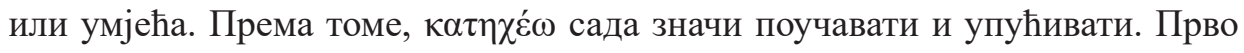
на шта нас ова ријеч асоцира јесте настава и школско образовање. Између учитеља и ученика се као ехо размјењују мисли и ријечи. Учитељева поука је одговор на ђачко питање, а ученик узвраћа када га учитељ пита. У давна времена био је обичај да ученици гласно, заједнички и у збору понављају одговоре и тако савладавају предметно градиво. Све то ствара утисак шума, буке, зова и одзива. Зато је било готово неизбјежно да се образовно дјелова-

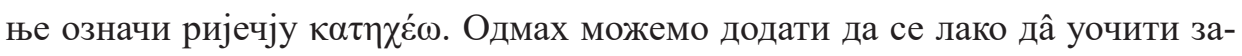
што је ова ријеч нашла своје мјесто и у Новом Завјету. Поука у вјери готово да и није друго до звук, одраз и ехо. Бог је изговорио своју Ријеч, и до нас је та Ријеч стигла у личности Исуса Христа, који нам ју је благовијестио кроз своје Јеванђеље. У проповиједи Ријеч звони и одзвања. Вјесници те Ријечи се труде да она зазвучи у срцима и ушима слушалаца. Тако проповиједници Ријечи шире и распростиру ту Ријеч свијетом. ${ }^{3}$

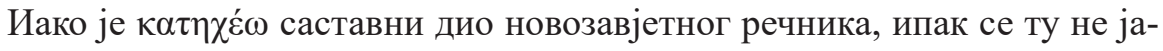
вља често, тачније, јавља се једино код Луке ${ }^{4}$ са значењем уйуйийи, оба-

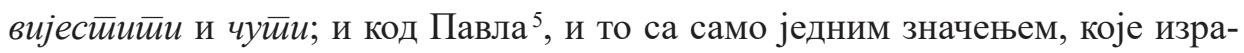
жава увођење и упућивање у хришћанску вјеру. Тако је Павле први који је

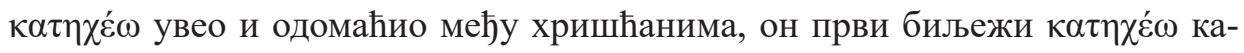
да је у питању вјерска поука, прије њега нико није тако свјесно поступио. ${ }^{6}$

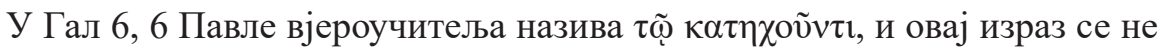
налази више нигдје у Новом Завјету, те се може рећи да га је он сам сковао.

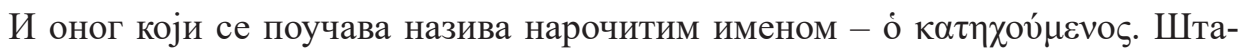
више, Павле овдје прописује да ученик треба да се брине за учитељево ма-

2 в. Mandac, y: Sveti Avgustin, нав. gјело, 14. Могло би се рећи да је то ехо који одзвања у души катихумена, када до њих допре катихетско излагање (в. Marijan Mandac, y: Grgur iz Nise, Velika kateheza, Makarska 1982, 9).

3 в. Mandac, y: Sveti Avgustin, нав. gјело, 15.

4 уп. Дап 18,25 и $21,21-24$.

5 уп. 1Кор 14, 19; Рим 2, 18 и Гал 6, 6.

6 в. Mandac, y: Sveti Avgustin, нав. яјело, 15. 
теријално добро. Све то упућује да у Гал 6, 6 имамо пред собом рани хришћански службени сталеж, који се бринуо за поуку о вјерским истинама. Према томе, већ Павле познаје звање кайихей $\hat{a}$, који живом ријечју поучавају кайихумене. ${ }^{7}$

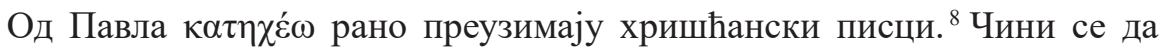
$\kappa \alpha \tau \eta \chi \varepsilon ́ \omega$ има сасвим одређено црквено значење већ у древној проповиједи која се приписује Клименту Римском, написаној и изговореној око 140. године:

„Покајмо се, зато, из свег срца, да неко од нас не пропадне. Јер ако имамо заповести да и ово чинимо: да одвраћамо (друге) од

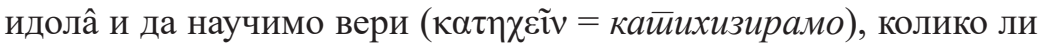
већма не треба да пропадне душа која већ познаје Бога?“. 9

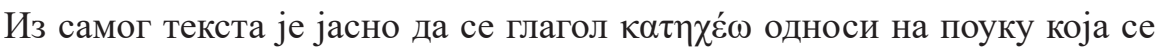
пружала људима који су се доста дуго и веома озбиљно припремали за свету тајну крштења кроз катихуменат, ${ }^{10}$ о чијем поријеклу и развоју током прва четири вијека живота наше Цркве ће и бити ријечи у поглављима која слиједе.

\section{Катихуменат у Новом Завјету}

Период катихумената представља припремни период за рађање у окриљу Цркве. Дакле, то вријеме припреме је предвиђено за катихизацију оних који се спремају за свету тајну крштења и миропомазања, у којој се, по ријечима саิмог Господа, сваки који се крсти рађа водом и Духом за Царство Божије (уп. Јн 3, 5). Тако је поучавање оних који се спремају за свету тајну просвјећења заправо било садржано у учењу и вјежбању новога живота, који је живот у Христу и који се суштински разликовао од живота нехришћана, односно живота под влашћу гријеха. Стога, катихизација се није исцрпљивала у интелектуалном упознавању истина Јеванђеља и правила црквеног живота, већ првенствено у практичном прилагођавању тим истинама и животу, а оно се могло остварити само кроз цјеловито дистанцирање од свог

7 в. Mandac, y: Sveti Avgustin, нав. gјело, 16.

8 уп. Lampe, 1961, 732 - 733.

9 Клименйова gруїа [йосланииа] Коринћанима, XVII, 1, у: Дела айостиолских учени$\kappa a$, Врњци - Требиње 2005, 199 - 200.

10 в. Mandac, y: Sveti Avgustin, нав. дјело, 16. 
„старог човјека” који је робовао гријеху. ${ }^{11}$ Овај процес дистанцирања од старог и прихватања новог живљења библијским језиком се назива $\mu \varepsilon \tau \alpha ́ v o l \alpha$, што има значење преумљења илити покајања. ${ }^{12}$

Као што ћемо видјети, овај период припреме за крштење постоји још од првих дана живота Цркве, с тим што се временом развијао и уобличавао, примајући одређену форму, какву срећемо у ранохришћанским списима. У првим годинама живота Цркве није постојала институција катихумената као таква и није спровођена дужа систематска припрема за крштење, ${ }^{13}$ што можемо видјети на примјеру Дјела апостолских. Међутим, поука, коју је изговарао неко од апостола̂, неминовно је претходила крштењу, те је тако апостолска проповијед заправо била припрема за крштење. Штавише, са̂мо покајање, обраћење, исповиједање вјере у Христа и крштавање било је управо последица овако једне снажне поуке.

Читајући друго поглавље Дјела апостолских, видимо да је на дан Педесетнице крштено око тири хиљаgе gуша, то јест крштени су они који раgо иримише ријеч апостола Петра (уп. Дап 2, 41). Тако, Петрово обраћање Јудејима (в. Дап 2, 22 - 36 и $38-40$ ), његова проповијед васкрслог Христа, није ништа друго до ли преткрштењска катихеза. Идући даље, наилазимо на сличну ситуацију у осмом поглављу Дјела апостолских: народ у Самарији, који је йазио јеgнояушно на Филипову проповијед о Царстиву Божијем и о имену Исуса Христиа, йовјероваше и критиаваху се (Дап 8, 6 и 12). Чак, говори, да за вријеме Апостолове проповиједи gухови нечисти с великом виком излажаху из мнойих који их имаху (Дап 8,7 ) - ово је веома значајно јер у постапостолском периоду, као што ћемо видјети, период катихизације под-

11 На основу неких новозавјетних мјеста (уп. Рим 2, 17 - 18) стиче се утисак да се цио старозавјетни Закон у то вријеме поимао као поука, катихеза. Исто тако у Новом Завјету наилазимо на свједочанство да се под поуком, која је била упућена хришћанима у то вријеме,

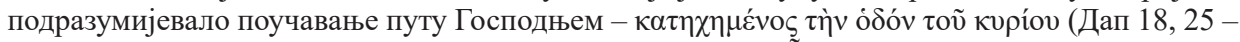

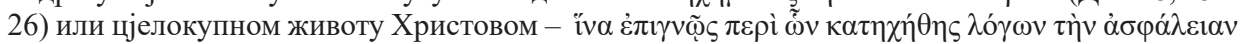
$($ Лк 1,4$)$, а не пуко поучавање појединим истинама вјере. То значи да је цио садржај Новог Завјета схватан као катихеза. Из таквог схватања развиле су се у првим вијековима живота Цркве двије врсте катихеза: катихезе за оне који се припремају за крштење и мистагошка катихеза за новокрштене, која има за циљ да новопросвијећене уведе у дубље тајне вјере Христове и савршеније степене живота у Христу. Циљ и једне и друге катихезе био је постепено увођење у догмате вјере и просвјећивање ријечју Божијом, кроз ослобађање вјерних од ла-

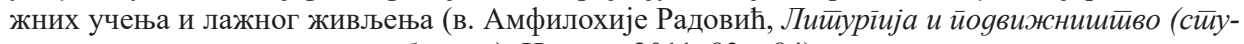
gије, есеји, чланци, ирикази и бесјеgе), Цетиње 2011, 83 - 84).

12 в. Ненад Милошевић, У Духу и исиини, лийуріичко - канонске иееме, Београд 2011, 18, нап. 9.

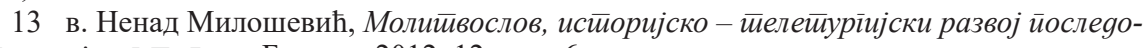
вања йарохијскої йийика, Београд 2012, 12, нап. 6. 
разумијева и свакодневно вршење егзорцизама или заклињачких молитава ${ }^{14}$ над онима који се спремају за свету тајну просвјећења. И овдје, као и у претходном случају, видимо да сабрани народ слободно исповиједа вјеру у Исуса Христа и жели да се крсти, јер је познао Ријеч истиниту, ${ }^{15}$ и зато би велика pagocū (Дап 8, 8). Све то нам свједочи о зачетку новога живота, живота у Христу, и хођењу у Духу Светоме.

Да катихизација засигурно претходи крштењу, видимо и на следећем примјеру у истом поглављу Дјела апостолских, гдје апостол Филип једном Етиопљанину, ушкопљенику, тумачити Писмо и проповиједа му јеванђеље о Иcycy (Дап 8, 26 - 35). Етипољанин са̂м тражи да се крсти и исповиједа вјеру у Христа - Вјерујем gа је Исус Христиос Син Божији ${ }^{16}$ (Дап 8, 37), коју је Филип и поставио као услов за крштење - Ако вјерујеш og свеї срияа, може (Дап 8, 37). Сем тога, оно што је за нас овдје нарочито значајно јесте пита-

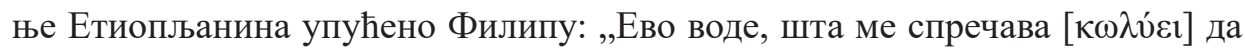
се крстим?” (Дап 8, 36). И на неким другим мјестима у Новом Завјету гла-

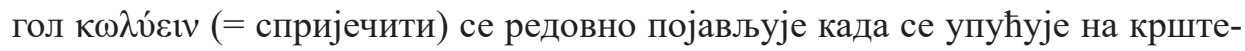
ње. ${ }^{17}$ Изгледа да је ово питање, ${ }^{18}$ које се односило на то да ли постоји некаква препрека за кандидата да се крсти, временом постало обредно питање. У сваком случају, из овог питања би се могло закључити да је већ у првим вијековима вршена провјера оних који приступају светој тајни просвјећења, да ли за њих постоји каква препрека за примање те свете тајне. ${ }^{19}$ Ово наглашавамо због тога што ће катихизација у каснијем периоду неизостав-

14 У раним вијековима, као и у каснијим временима, уобичајена форма егзорцизма је била једноставна и ауторитативна наредба упућена демону у име Божије, а нарочито у име распетог Христа, да изађе и да напусти онога кога је опсједнуо својом тамом (уп. Lawrence D. Folkemer, A Study of the Catechumenate, y: Church History, Vol. 15, No. 4 (Dec., 1946), 296).

15 А могао је и да ју је не (пре)позна и одбаци, будући да су претходно били завођени Симоновим враџбинама, говорећи за њих: „Ово је велика сила Божија" (Дап 8, 9 -10). Не можемо ни замислити колико је била силна и снажна проповијед апостола Филипа, када је такав један заведени народ обратио Христу. И не само народ, него и самог Симона.

16 Ове ријечи Етиопљанина могле би се сматрати најстаријом формом крштењског исповиједања вјере (в. Милошевић, Молийвослов, 12, нап. 8).

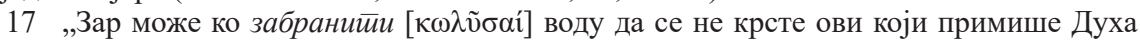
Светога као и ми?” (Дап 10,47$) ;$ „Ако им, дакле, Бог даде једнак дар као и нама који повје-

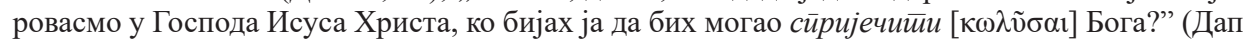

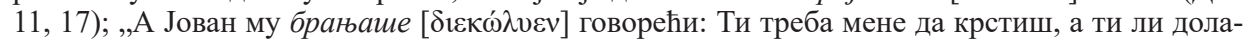
зиш мени?" (Мт 3, 14).

18 Упркос очигледној правилности са којом је ово питање постављено у сва четири случаја у Новом Завјету, не може се, међутим, утврдити ко је тај ко ово питање поставља. Некад је то лице које треба да се крсти (уп. Дап 8, 36 и Мт 3, 14), а некад и неко треће лице (уп. Дап 10, 47 и 11, 17), које је имало неку улогу кума (в. Оскар Кулман, Крииееъе у Новом Заветиy, Београд 2011, 83).

19 в. Кулман, нав. яјело, $78-79$. и 82. 
но подразумијевати вишеструко и вишегодишње испитивање оних кандидата који се спремају за крштење. Те тако, можемо рећи, да потоње не представља никакву новину у односу на новозавјетну праксу, већ само њен даљи наставак и развој.

Дјела апостолска нам такође саопштавају да се апостолу Павлу, док је још био Савле - озлоглашени гонитељ хришћана, са̂м Господ јавио на путу за Дамаск као Онај кога Савле гони, и тај догађај је толико потресао Савлову душу да се крстио одмах након што је прогледао, будући да је ослијепио од виђња небеске свјетлости (уп. Дап 9, 3 - 18). Видимо да непосредно пред крштење Савле проводи три дана у посту и молитви (уп. Дап 9, 9 и 11), што ће касније постати један од конститутивних дијелова преткрштењске катихизације. Дакле, у овом случају са̂м Господ се јавља и са̂ма Његова објава бива савршена преткрштењска катихеза. Да овај догађај не би био сматран утваром, Господ шаље Савлу ученика Ананију који ће и да потврди то што се збило - заиста ти се јавио Господ, и сад прогледај и прими Духа Светога (уп. Дап 9, 17).

У самој својој сржи катихеза је прије свега ријеч спасења, што видимо приликом крштења Корнилијевог дома од стране апостола Петра: ријеч коју ће Петар рећи јесте ријеч спасења (уп. Дап 10,6), а та ријеч је заправо преткрштењска катихеза (уп. Дап 10, 34 - 43) и кроз њу се на слушаоце ријечи излива Дух Свети, ${ }^{20}$ то јест на све оне којима Господ отвори срце да је чују (уп. Дап 16, 14).

Као што смо досад запазили - гдје год је било помена крштења, том крштењу је претходила поука. Ни надаље нема изузетка, те је то случај и са крштењем: Лидије и дома њеног у Тијатири (уп. Дап 16, 13 - 15), тамничара и свих његових (уп. Дап 16, 30 - 33), Криспа и свег дома његовог и многих Коринћана који слушаху ${ }^{21}$ апостола Павла (уп. Дап 18, 8), као и ученика̂ у Ефесу (уп. Дап 19, 1 - 5).

Уочили смо да преткрштењски период, ма колико он трајао, неизоставно и као његов структурални дио прати поука која бива упућена од стране неког од апостолаิ. Ту поуку прате и покајање, и егзорцизми, и испитивања кандидата, и исповиједање вјере, и молитва, и пост, и све оно што ће каснијом ус-

20 Дакле, катихизација нипошто није пуко поучавање некаквим вјерским истинама, већ управо даривање Духа Светога, јер нико не може рећи: Исус је Госйоg, осим Духом Све$\bar{u} и м$ (1 Кор 12, 3). Тако, Дух се даје ријечју, али Дух може и забранити ријеч (уп. Дап 16,6) и ту ријеч не могу да приме сви који је чују (уп. Дап 18, 6), јер нису пријемчиви дару Духа Светога.

21 Након овога Павле остаје у Коринту годину и шест мјесеци учећи их ријечи Божијој (Дап 18, 11), тј. упућујући им мистагошке катихезе. 
поставом катихумената чинити управо његову структуру. Током даљег развоја катихизације ови елементи остају њен трајни садржај. Из наведеног се недвосмислено даิ закључити да катихуменат своје поријекло има директно у ријечи апостолаิ, штавише - у самим ријечима Спаситеља: „Идите, дакле, и научите 22 све народе крстећи их у име Оца и Сина и Светога Духа" (Мт 28, 19).

Одјељци из Дјела апостолских, које смо наводили, свједочанство су ступња развоја у којем су покајање и вјера били једини услови за крштење. Међутим, са каснијом установом катихумената Црква ће настојати да врши испитивања подобности кандидата̂ и чистоте њихових намјера, и одбациваће оне који слиједе позив неспојив са статусом крштеног хришћанина. Али изнад свега било је неопходно захтјевати одређену дефиницију вјере у Христа. Сажете формуле више нису биле довољне. Црква ће од кандидата̂ захтјевати усвајање поуке потврђене од свједока̂. Ово ће бити спољашњи услов чије ће остваривање довести до тога да не постоји више ништа што „спрјечава” крштење. Мјесто једноставног обредног питања, о коме смо говорили изнад, преузима институција са комплетном организацијом, која ће бити уређена до најситнијих појединости. ${ }^{23}$

Сходно свједочењу Дјела апостолских, будући да се у актуелном периоду не може говорити о некаквој дефинисаној и уређеној форми кайихуме-

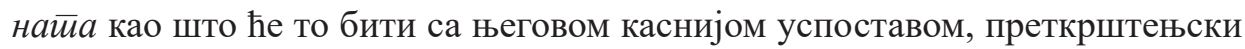
период карактеришу следећи елементи:

$$
\begin{aligned}
& \text { - преткрштењска катихеза } \\
& \text { - егзорцизми } \\
& \text { - испитивање кандидата } \\
& \text { - покајање или одрицање } \\
& \text { - исповиједање вјере } \\
& \text { - молитва и пост }
\end{aligned}
$$

Надаље ћемо да видимо како су се ови елементи током наредног периода развијали и структурисали у оквирима катихумената, који је на њима и установљен.

22 У Айосйолским устиановама имплицитно се наглашава да је овим ријечима са̂м Господ установио крштењску катихизацију: „Због тога нам је Господ говорио (опоменуо нас), прво, Начините народе ученицима својим; и онда је додао ово, и крстите их у име Оца, и Сина и Светога Духа" (The Constitutions of the Holy Apostles, New York - Philadelphia 1848, VII, XL, 190).

23 в. Кулман, нав. gјело, $86-87$. 


\section{Катихуменат у постапостолском периоду}

Већ крајем другог вијека, у све већем броју оних који су жељели да постану чланови евхаристијске заједнице, Црква је препознала потребу да систематизује припремни период за свету тајну крштења. Стога су такве потребе и околности учиниле да Црква већ веома рано установи катихуменат као вријеме припреме за крштење. ${ }^{24}$

Структурални крштењски елементи, о којима свједочи Нови Завјет, у постапостолском периоду добијају цјеловитију и садржајнију литургијску форму. Као битна карактеристика издваја се и то што се цјелокупна припрема за крштење, као и са̂мо крштење, одвијају у оквиру црквеног сабрања, што значи да је цијела Црква упозната са новим члановима. На основу сачуваних свједочанства о крштењској пракси постапостолског периода можемо формирати прилично јасну слику о начину вршења катихизације у прва три вијека. Стога, како бисмо могли пратити даљи развој катихумената, у томе нам је од велике помоћи и важности постојање неколико литургичко - канонских списа и свједочанства појединих апостолских ученика, првенствено Јустина Философа и Мученика, Тертулијана и Иполита Римског, који дају јасну слику о припремном периоду за свету тајну крштења. ${ }^{25}$

Током другог стољећа катихуменат има наглашенији практични дио, неголи доктринарни. Тако, на примјер, првих шест поглавља Дияахија говори о хришћанском животу и владању. Айосииолске устианове, рецимо, баве се карактером и праксом вјерних, и кроз свих својих осам књига непрестано стављају нагласак на морални живот. Свети Јустин Мученик налаже катихуменима да ступе у живот молитве и поста, како би задобили опроштење својих сагрјешења. Али закључак није тај да су доктринарна питања била игнорисана, већ да је потпунији развој догматских учења дошао тек касније. ${ }^{26}$

24 в. Folkemer, нав. gјело, 286.

25 в. Милошевић, Молииввослов, 13.

26 в. Folkemer, нав. gјело, 286 - 287. и 293., нап. 42. Свети Кирило Јерусалимски на савршен и једноставан начин обједињује ово двоје: „Начин богопоштовања садржи се у овим двема принадлежностима: у тачном познању побожних догмата и у добрим делима. Догмати без добрих дела нису по вољи Божијој; Он чак ни дела не прима ако нису заснована на побожним догматима. Каква је корист ако се добро познаје учење о Богу, а срамотно се блудничи? Са друге стране, каква је корист ако се живи како треба, уздржљиво, а срамотно се богохули? Дакле, знање догмата и бодрост душе представљају велики добитак" (Свети Кирило Јерусалимски, нав. яјело, 4, 2, 43 - 44). 


\section{Дидахи, Јустин и Тертулијан}

Прво извјесно свједочанство за период формирања и припреме за крштавање налазимо код Јустина Философа и Мученика у његовој Aйолоїuju I (150 - 155. год.). Преткрштењска припрема о којој Јустин говори, није била строго и методично организована, али је ипак постојала. Али већ педесет година након тога, почетком трећег вијека, ситуација се измијенила. Гностици, маркионисти и монтанисти, својим погрешним и јеретичким учењима, подстакли су Цркву да се са већим жаром посвети прецизнијем изражавању догматских истина и да озбиљније приступи припремању кандидата за крштење. ${ }^{27}$

Сем што нас извјештава о припремном периоду за крштење, који се огледа у молитви, посту и покајању, Јустин нам свједочи и са којом пажњом је Црква држала до човјекове богомдане слободе да се опредијели за Христа и за Цркву Његову или пак да то не учини, јер вјера јесте увијек слободан акт свакога човјека као слободне личности. Тако, Јустин записује следеће:

„Ако се неко убеди и увери да је учење наше истинито и да су нам речи добронамерне и ако такав схвати да би могао да живи у заједници са нама, такве саветујемо да се молитвом и постом обрате Богу и измоле опроштај пређашњих грехова, а и ми сви ћемо заједно са њим молити се и постити." 28

А још прије Јустина у Дияахију (друга половина 1. вијека) такође налазимо сличне упуте који се тичу поста:

„А пре крштења нека претходно посте онај који крштава и крштавани, и ако неки други могу. А наредићеш крштаваноме да пости један или два дана раније.”29

Поред ова два свједочења и Тертулијан у свом спису De baptismo (198 - 207. год.) говори:

27 в. Пол Харкинс, Злайоустиове йослекрииенъске йоуке, у: Беседа, књ. 1, свеска 2/3/4 (1991), 80 .

28 Јустин Мученик, Айолоїија I, 60, у: Свети Јустин философ и мученик, Сабрана gела, Београд - Ваљево - Србиње 2002, 49. Шмеман, осврћући се на ове Јустинове ријечи, говори: „Крштење јесте тајна Царства; у њему учествује, њиме се обогаћује сва Црква, тако да и у припреми за ту тајну треба да учествују сви" (Александар Шмеман, Увоg у лийуріиччко бойословље, Шибеник 2013, 114).

29 Дияахи VII, 4, у: Дела айосйолских ученика, Врњци - Требиње 2005, 123. 
„Oni koji namjeravaju pristupiti krštenju treba da se mole čestim molitvama, postovima, klanjanjima i bdjenjima. Uz to ispovijedaju sve grijehe iz prošlosti da bi ostvarili i Ivanovo krštenje." 30

Сем наведеног, Тертулијан не говори више ни о каквим појединостима по питању катихумената, иако је сам спис намијењен катихуменима, ${ }^{31}$ али наглашава да је потребна зрелост код оних који желе да слушају поуку, то јест да дођу кад буду способни да упознају Христа, како би и знали гдје долазе. ${ }^{32}$

\section{Иполит Римски}

Захваљујући веома раном успостављању катихумената, припреме за крштење катихумена протежу се на дужи временски период од најдуже три године, ${ }^{33}$ о чему нам свједочи Иполит Римски у свом Айосйолском йреgағу (217. год.), које садржи најопсежнији опис крштењске праксе у овој епохи. Тако се у овом дјелу прописује следеће:

„Катихумени (= ойлатени, йоучавани у вери) нека слушају реч (науке) током три године ${ }^{34}$. Али, ако је неко ревностан и добро

30 Kvint S. F. Tertulijan, Spis o krstu, Zagreb 1981, 20, 1, 85.

31 уп. Tertulijan, нав. gјело, 1, 1, 43.

32 в. Tertulijan, нав. яјело, 18, 5, 83.

33 Циљ овог поучавања који је претходио крштењу није се састојао искључиво у томе да се поуче истинама вјере они који желе да ступе у Цркву, него да се стекне увјерење о искрености њиховог покајања. Неопходност претходног испитивања нарочито је постала изражена у вријеме прогона, када су почели у великом броју да се појављују „пали” (в. Николај Афанасјев, Сйуйање у Цркву, Краљево 2008, 107). Тако, свети Кирило Јерусалимски, у свом обраћању катихуменима, говори: „Као што се при регрутовању младића за војску мотри на узраст и телесно здравље, тако и Господ, бирајући душе, испитује вољу. Ако се установи да је у неком прикривено лицемерје, такав се одстрањује као неспособан за истинско служење. Свакоме ко се нађе достојан, дарује се благодат: не gајие свеиииње йсима, него на коме се види чиста савест, на томе се полаже спаситељни и чудесни печат од кога дрхте злодуси и који познају анђели да би први, као прогањани, побегли, а ови други, као своји, заједничарили са њим. Сви који примате овај духовни и спасоносни печат, треба да имате и слободну вољу за њега. Као што је за мач или за перо потребан делатник, тако је и за благодат потребан верник" (Свети Кирило Јерусалимски, нав. яјело, 1, 3, 20).

34 Елвирски сабор (306. год.) у свом IV канону прописује да жречеви треба да буду поучавани три године, и ако би се уздржавали од жртвовања која су раније вршили, бивали би крштени. Исти сабор у XLII канону прописује да они који уживају извјесни углед и желе да постану Хришћани, треба да слушају поуку двије године, прије него што буду крштени. Али, уколико се у међувремену разболе (на смрт), могу бити крштени и раније. Јустинијан (6. вијек) у својој CXLIV новели прописује вријеме трајања катихизације на двије године, сматрајући да не треба журити са крштавањем оних који желе да се крсте (уп. The Novels Of Justinian, Cincinnati 1932, 144, II). Каснији канони и пракса Цркве ће скратити ово врије- 
усрдан за ствар (Хришћанства), нека не пресуђује време него судите само по начину живота (његовог)." 35

Сама припрема се састојала из систематизованих поучавања, честих молитава, вишедневног поста, кољенопреклањања, молитвених бдења и исповијести. Оваква црквена дисциплина, која се односила на катихуменат, у наставку ће пресудно утицати на уобличавање других црквено - литургијских дисциплина које ће постати редовна и обавезна црквена пракса. Ту се прије свега мисли на општеобавезни четрдесетодневни пост, а онда и на неизоставне јектеније за катихумене на свим црквеним богослужењима. ${ }^{36}$

Према свједочењу Иполита Римског, они који први пут долазе да слушају поуку, треба да буду доведени ${ }^{37}$ пред учитеље прије него што се сав народ окупи, да би били испитани разлози њиховог приласка хришћанској вјери. Кандидати су пред учитељима исповједно признавали своје пороке, али су, истовремено, били од њих позивани да прекину са својим лошим навикама. ${ }^{38}$ Они би прво били испитивани за њихов начин живљења, да ли су у браку и да ли су робови. Робови су могли слушати ријеч само ако би њихов господар потврдио да су они добри, у супротном би били враћени. А уколико би њихов господар био незнабожац, робови би тада били поучени да је потребно да буду послушни своме господару, како га не би тиме подстакли да хули на хришћанску вјеру (уп. 1Тим 6, 1), те да из тог разлога не примају ријеч науке. Исто тако је потребно поучити и оне који живе у браку да буду задовољни једно другим, и оне који не живе у браку да не чине блуд. Осим тога, ђавоиманим није дозвољавано да приступе катихизацији док се не би очистили од нечистих сила. ${ }^{39}$

ме трајања катихизације, чија ће дужина потпуно зависити од жеље и моралног напретка катихумена (уп. Folkemer, нав. gјело, 290).

35 Айостиолско ирреgање, 17, у: Дела айостиолских ученика, Врњци-Требиње 2005, 392.

36 в. Милошевић, Молитивослов, 13 - 14. Све до данас је сачувана пракса произношења јектенија за оглашене на свим литургијама током годишњег богослужбеног круга, али и јектеније за оне који се спремају за свето просвјетљење од сриједе четврте недјеље Четрдесетнице па до Велике сриједе. Ове јектеније су се, у тзв. азматском типику, произносиле и на последовањима дневног круга (вечерње, јутрење и тритекти), као и при свим другим последовањима: крштење, сахрана, освећење храма, освећење мира и монашки постриг (в. Ис$\bar{u} о, 14$, нап. 18).

37 Каже се да треба да буду доведени, зато што су их приводили учитељима управо они који би посвједочили да их знају и да су способни да слушају ријеч.

38 в. Милошевић, Молитивослов, 15. Искрено покајање, самоодрицање, чисте намјеpe, све то је требало да посједује онај ко жели да приступи заједници вјерних (уп. Folkemer, нав. gјело, 293). А о томе да је крштењу приступано из најразличитијих побуда говори и св. Кирило Јерусалимски (уп. Свети Кирило Јерусалимски, нав. яјело, Уводна поука, 2 - 5, 9 - 11).

39 в. Айосииолско ирреgање, 15, у: нав. яјело, $390-391$. 
Након овога слиједи испитивање о пословима и занимањима новообраћених, те се у Айосииолском йреgағу детаљно наводи ко све не смије бити припуштен поучавању. Рана Црква је била нарочито строга и дистанцирана према појединим занимањима и пословима, будући да су извјесне службе и послови били повезани са паганством и идолослужењем. У том смислу се и учитељима који су учили у школама забрањује да слушају ријеч, уколико не престану од свог учитељства, будући да је наука коју су предавали свакако била паганска. Међутим, Црква овдје ипак снисходи, па каже: „... а ако нема gруїо занимање, нека му се gозволи (кайихизаиија).“40 Али Црква никако није била снисходљива према онима који су се бавили срамним пословима или су учествовали у било каквим многобожачким и идолопоклоничким култовима (блудници, умјетници, гладијатори, војници ${ }^{41}$, врачари итд.), или су пак живјели онако како није било допуштено. У том случају нису припуштани катихизацији, сем уколико не би престали од гријеха и покајали се. ${ }^{42}$

Пошто би са искреношћу исповиједили своје животе и прихватили заповијести Цркве захваљујући учитељима, такви су примани у сталеж катихумена настојећи да се, током цјелокупног трајања катихизације, удаље од својих претходних навика и вјежбају у живљењу по заповијестима Јеванђеља. То је, дакле, било вријеме покајања које се огледало у снажном одрицању и дистанцирању од ђавола и дјела таме. За овакав подвиг, уз редовна и систематизована поучавања јеванђелским истинама и заповијестима хришћанског живљења, били су неопходни пост и молитва јер се, по ријечима самог Господа, $\bar{u}$ ај pog изїони само йостиом и молийвом (Мк 9, 29). ${ }^{43}$

Поучавања тим јеванђелским истинама су вршена свакодневно, а након тога катихумени би се молили засебно, одвојени од вјерника. По завршеној молитви учитељ би, било да је клирик или лаик, полагао руке на катихумене и молио се, а онда би их отпуштао. ${ }^{44}$ Током свеукупног времена катихизације катихумени су редовно бивали на свим богослужењима и учествовали у њима до момента када су, путем јектеније за катихумене, удаљавани са сабрања. ${ }^{45}$

40 в. Айостиолско йреgање, 16, у: нав. яјело, 391. и нап. 9.

41 Војници су бивали припуштани катихизацији само уколико би положили заклетву да неће убијати. А ако, пак, катихумен или вјерник хоће да буде војник - треба да буде одбијен, јер они презиру Бога (в. Айосииолско йреgање, 16, у: нав. gјело, 391).

42 в. Айосииолско ирреgање, 16, у: нав. яјело, $391-392$.

43 в. Милошевић, Молииввослов, 15.

44 в. Айостиолско йреgање, 18 - 19, у: нав. яјело, 392 - 393.

45 в. Милошевић, Молийвослов, 16, нап. 28. 
Након извјесног времена из реда катихумена се бирају они који ће бити крштени, и тада се испитује начин њиховог живљења током периода катихизације, при чему су им свједоци они који их и приводе. На основу свједочења Иполита Римског видимо да је заправо суштина овог пропитивања да се дозна да ли је катихумен заиста живио по Јеванђељу, то јест да ли је (до)живио истинитост Христових ријечи: ,Заиста вам кажем: каg учинисйе јеgноме оg ове моје најмағе браће, мени учинистие“ (Мт 25, 49). Уколико њихови свједоци потврде да су се владали по Јеванђељу, онда им свакодневно врше егзорцизме, полажући на њих руке. Када се приближи дан крштења, епископ чини последњи егзорцизам над катихуменима и поучава их да се окупају у четвртак. Пошто се сви окупе на једном мјесту у дан суботњи, свима заповиједа да се моле клечећи, док он врши заклињање свакої сйраної gуха. Уколико би се нашло да неко није gобар или није чисти, изgваја се насамо, јер није слушао реч (науке) са вером. Након заклињања епископ им дува у лице и закрштава им чело, уши и ноздрве, а онда их подиже на ноге. Они који ће се крстити посте један дан (= петак), а ноћ пред крштење проводе у бдењу и слушању поуке, ${ }^{46}$ коју ће слушати и као новокрштени. ${ }^{47}$

У недјељу, рано изјутра, бива молитва над водом. Епископ узноси молитву над уљем благодарења и врши заклињање над уљем заклињања. Та уља узимају ђакони и стоје здесна и слијева презвитеру, који заповиједа крштаванима да се одрекну ђавола ријечима: „Ояричем се, йебе, Сайано, и

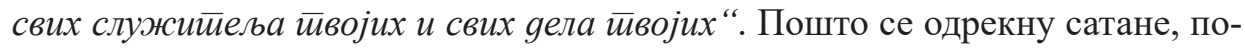
мазује их уљем, говорећи: „Нека се ygaљи og иеебе сваки зли gух“. Затим, када сиђе у воду, онај који крштава пита крштаваног: „Верујеш ли у Боїа Oйа Свеgржитељља?“, а крштавани одговара: „Верујем“. Тако бива трократно испитан да ли исповиједа вјеру у сва три лица Свете Тројице, и након сваког верујем бива погружен у воду. ${ }^{48}$

Из свега наведеног видимо да рана Црква нипошто није тек тако и олако примала било кога у своје окриље, већ је и те како настојала да у човјековом срцу п(р)обуди искрену жељу да се присаједини Христу ${ }^{49}$ (или пак да

46 в. Айостиолско ӣреgање, 20, у: нав. яјело, 393 - 394.

47 Иполит говори да епископ пружа објашњења новокрштенима прије него што ће ови примити причешће, а ако још буде требало штогод да их поучи, вели да ће то учинити у тајности (в. Айосииолско йреgағе, 21, у: нав. яјело, 398 - 399).

48 в. Айостиолско йреgање, 21, у: нав. яјело, $394-396$.

49 Како нам и свједочи св. Кирило Јерусалимски, говорећи: „Иако је Бог штедар у добротворству, ипак од свакога очекује нелицемерну жељу... Искрена намера чини те позваним" (Свети Кирило Јерусалимски, нав. gјело, Уводна поука, 1, 9). 
препозна искреност те жеље са којом неко приступа Цркви), како Га се не би касније одрекао и потоње му било горе од првога (уп. Мт 12, 45).

Осврћући се на до сада речено, катихуменат у постапостолском периоду је имао следећу структуру ${ }^{50}$ :

- испитивање оних који се појављују први пут да би слушали катихизацију

- трогодишња припрема катихумена - катихизација

- испитивање и издвајање катихумена прије него што ће се крстити

- свакодневни егзорцизми уз полагање руку на оне који се спремају за просвјетљење

- $\quad$ када се приближи дан крштења, епископ врши егзорцизам над сваким појединцем и испитује њихову достојност за крштење и поучава их да се окупају у четвртак

- они који ће се крстити посте у петак

- сабрање свих на једно мјесто у суботу, када епископ врши последњи егзорцизам над онима који ће се крстити

- после егзорцизама епископ им дува у лице, закрштава им чело, уши и ноздрве

- катихумени проводе цијелу ноћ уочи крштења бдијући и поучавајући се читањем и катихизирањем

- крштавани се одричу сатане и бивају помазивани уљем заклињања

- крштавани се погружавају (крштавају) у води трократним исповиједањем вјере

Након овог разматрања, уколико наведену структуру катихумената постапостолског периода упоредимо са оним новозавјетним преткрштењским елементима, о којима је било ријечи у претходном поглављу, моћи ћемо лако да уочимо њихов развој и структурално уређење до актуелне епохе. Испитивање кандидата, које у Новом Звјету налазимо у виду обредног питања $^{51}$, овдје се спроводи систематски и то на више нивоа: прије почетка катихизације, прије крштења и пред само крштење. Апостолску проповијед замијенила је трогодишња катихизација, која се интезивно одвија до самог крштења, али и након њега. Егзорцизми више нису само последица апостолске проповиједи (уп. Дап 8, 7), већ се врше свакодневно и континуирано до дана крштења. Као и у Новом Завјету, дужина трајања преткрштењског по-

50 Користили смо се структуром свете тајне иницијације коју је проф. Милошевић изложио у својој студији (в. Милошевић, Молийвослов, 16 - 17).

51 уп. Дап 8, 36; 10, 47; 11, 17 и Мт 3, 14, о чему је било ријечи раније. 
ста још увијек није прецизно дефинисана, али углавном су то један или два дана. Све вријеме трајања катихизације катихумени проводе у молитви и покајању, о чему налазимо свједочанства и у Новом Завјету (уп. Дап 2, 37 $38 ; 9,11$ и 10, 1 - 4). За овај период је такође карактеристично и уобличавање формуле одрицања од сатане и исповиједања вјере у Свету Тројицу, које у Новом Завјету налазимо као исповиједање да Исус Христос јесте син Божији (уп. Дап 8, 37).

Као што примјећујемо, структура катихумената је у овом периоду добила далеко садржајнији, богатији и цјеловитији израз, чиме нам је предочено несагледиво материнско старање и брига Цркве за оне који ступају под њено окриље. Сав овај развој и процват катихумената ће бити још израженији и употпуњенији током наредних стољећа, о чему ће бити ријечи у неком другом раду.

\section{Литература}

Айосииолско йреgање у: Дела айосӣолских ученика, Јевтић А. (пр.), Врњци - Требиње 2005, 383-409.

Афанасјев Николај, Сйуйање у Цркву, Краљево 2008.

Дияахи - Учење Дванаесториие Ученика у: Дела айосйолских ученика, Јевтић А. (пр.), Врњци - Требиње 2005, 119-129.

Јустин Мученик, Айолойја І уйућена Аниионину Побожном у оgбрану хришћансиива, у: Свети Јустин философ и мученик, Сабрана gела, Мијатов М. (пр.), Београд - Ваљево - Србиње 2002, 11-56.

Клименйова gруїа [йосланица] Коринћанима у: Дела айосйолских ученика, Јевтић А. (пр.), Врњци - Требиње 2005, 191-202.

Кулман Оскар, Кршишење у Новом Завеш̄у, Београд 2011.

Милошевић Ненад, Молийвослов, исииоријско - иелеииуріијски развој йослеgовања йарохијской йийика, Београд 2012.

Милошевић Ненад, У Духу и истиини, литиуріичко - канонске иееме, Београд 2011.

Нови Завјеши, САСинод СПЦ (пр.), Београд 2009.

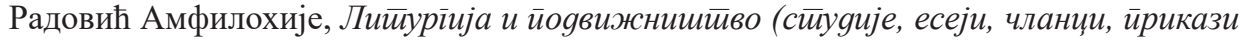
и бесјеgе), Цетиње 2011.

Свети Кирило Јерусалимски, Кайихезе, Мијатов М. (пр.), Београд - Ваљево Србиње 2001.

Харкинс Пол, Злайоусииове иоослекршишењске йоуке, у: Бесеgа, књ. 1, свеска 2/3/4 (1991), 79-89.

Шмеман Александар, Увоg у лийуріичко бойословље, Шибеник 2013.

Folkemer Lawrence D., A Study of the Catechumenate, y: Church History, Vol. 15, No. 4 (Dec., 1946), 286-307.

G. W. H. Lampe, A patristic greek lexicon, London 1961. 
Grgur iz Nise, Velika kateheza, Mandac M. (пр.), Makarska 1982.

Kvint S. F. Tertulijan, Spis o krstu, Mandac M. (пр.), Zagreb 1981.

Sveti Avgustin, Poučavanje neupućenih, Mandac M. (пр.), Makarska 1988.

The Constitutions of the Holy Apostles, Chase I. (пр.), New York - Philadelphia 1848.

Интернет извори:

The Novels Of Justinian, Scott S. (пр.), Cincinnati 1932, на: http://droitromain.upmf-grenoble.fr/Anglica/Novellae_Scott.htm (приступљено 28.7.2016)

\title{
Deacon Lazar Djacic
}

The Church of The Holy Ascension, Subotica

exapostilar@gmail.com

\section{THE ORIGIN AND DEVELOPMENT OF THE CARECHUMENATE IN THE ANCIENT CHURCH}

\begin{abstract}
Summary
In this work we will talk about the origin and development of catechumenate in the ancient Church, and, consequently, we will give a brief overview of the origin and

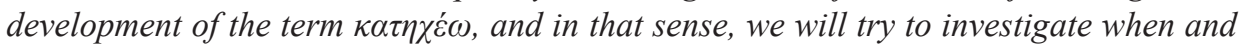
where this term first appears, with what meaning and how its meaning developed and formed until its use in Christian literature. We will further talk about the pre-baptismal period in the New Testament, that is, about the beginnings of the catechumenate its development and fulfillment in the coming centuries. Accordingly, our goal is to identify all those pre-baptismal elements, which will serve as a basis for the establishment of catechumenate in later centuries, primarily on the example of one of the New Testament writings, specifically the Acts of the Apostles. Thus, in the foreground, we intend to emphasize the continuity of the development of the catechumens in the Church from the first days of its life.
\end{abstract}

Keywords: catechumenate, baptism, Acts of the Apostles, catechesis, exorcism, confession of faith 